\title{
CC and CXC chemokines play key roles in the development of polyomaviruses related pathological conditions
}

\author{
Mohammad Hassan Mohammadi ${ }^{1}$ and Ashraf Kariminik ${ }^{2^{*}}$
}

\begin{abstract}
It has been reported that polyomaviruses are the microbes which can be a cause of several human pathological conditions including cancers, nephropathy, progressive multifocal leukoencephalopathy and gynaecological disease. Although investigators proposed some mechanisms used by the viruses to induce the disorders, the roles played by chemokines in the pathogenesis of polyomaviruses infections are yet to be clarified. This review article investigated recent studies regarding the roles played by chemokines in the pathogenesis of the polyomaviruses infections. The research in the literature revealed that CXC chemokines, including CXCL1, CXCL5, CXCL8, CXCL9, CXCL10, CXCL11, CXCL12 and CXCL16, significantly participate in the pathogenesis of polyomaviruses. CC chemokines, such as CCL2, CCL5 and CCL20 also participate in the induction of the pathological conditions. Therefore, it appears that CXC chemokines may be considered as the strategic factors involved in the pathogenesis of polyomaviruses.
\end{abstract}

Keywords: Polyomaviruses, CXC chemokines, CC chemokines, Nephropathy, Cancer

\section{Introduction}

It has been demonstrated that human polyomaviruses are the viruses responsible for inducing some pathologic conditions and malignancies in human $[1,2]$. However, both the JC and the BK viruses are potential risk factor for human disorders. For example, BK virus is the main cause of hemorrhagic cystitis in recipients of bone marrow transplantation, while JC virus can induce progressive multifocal leukoencephalopathy in immunocompromised patients [3]. Additionally, transplant nephropathy is another disease which is induced by BK virus infection, and is recognized as a main cause of renal allograft failure [3]. Moreover, it has been reported that various neoplastic disorders and autoimmune conditions are associated with infection with BK virus [3]. Due

\footnotetext{
*Correspondence: a.kariminik@iauk.ac.ir

${ }^{2}$ Department of Microbiology, Kerman Branch, Islamic Azad University, Kerman, Iran
}

Full list of author information is available at the end of the article to the fact that the JC and BK virus proteins can interact with a number of cellular target proteins in the central nervous system, they can dysregulate pathways involved in the cell cycle, DNA repair, and others, which are the main altered molecules during cancers [4]. Therefore, the viruses, especially JC virus, are considered as the potential inducers of brain tumors.

The main mechanisms used by the viruses to induce the disorders are yet to be clarified completely. It has been hypothesized that immune system may participate in the transformation of the target tissues [5]. Chemokines are the main molecules secreted by the immune and non-immune cells and are crucial for development of tumors and other complications [6]. This review article addresses the main mechanisms played by chemokines in the pathogenesis of polyomaviruses-related pathological conditions. original author(s) and the source, provide a link to the Creative Commons licence, and indicate if changes were made. The images or other third party material in this article are included in the article's Creative Commons licence, unless indicated otherwise in a credit line to the material. If material is not included in the article's Creative Commons licence and your intended use is not permitted by statutory regulation or exceeds the permitted use, you will need to obtain permission directly from the copyright holder. To view a copy of this licence, visit http://creativecommons.org/licenses/by/4.0/. The Creative Commons Public Domain Dedication waiver (http://creativeco mmons.org/publicdomain/zero/1.0/) applies to the data made available in this article, unless otherwise stated in a credit line to the data. 


\section{Introduction of polyomaviruses}

The human polyomaviruses are the $40-45 \mathrm{~nm}$ viruses which contain the spherical nonenveloped capsids and also the 5000 base pairs double-stranded DNA genomes $[1,2]$. Human polyomaviruses have a genome which is divided into two important regions called, the early and late regions [7]. Accordingly, the early and late regions code large $\mathrm{T}$-antigen and small $\mathrm{t}$-antigen, capsid proteins (VP)-1, VP-2, and VP-3, respectively [8]. Additionally, the late gene region in two important members of the polyomaviruses, BK and John Cunningham (JC) polyomaviruses, also code another protein, agnoprotein, which participates in the assembly of the viral capsid and also the virion release from the infected cells $[9,10]$.

As mentioned, BK virus is an important member of the polyomaviruses whose infection and activation are associated with various human clinical pathogenesis [5]. JC virus is another member of the polyomaviruses and was discovered in a patient who suffered from Hodgkin's lymphoma and progressive multifocal leukoencephalopathy (PML) [11]. Recent genomic sequencing technologies revealed 11 additional polyomaviruses such as human polyomavirus 3 (KI virus), 4 (WU virus), 5 (Merkel cell polyomavirus), 6, 7, 8, 9, 10 (Malawi or MW polyomavirus), 11 (Saint Louis polyomavirus), 12 and 13 (New Jersey polyomavirus) [11].

Although all of the polyomaviruses participate in the human disease pathogenesis, BK and JC viruses are the most important polyomaviruses regarding their related disease severities and also their prevalence among the human population [12-14]. The prevalence of BK and JC viruses is variable based on the age and location. However, epidemiological investigations, which were performed based on the seropositive reactions against BK and JC viruses, revealed that $65-90 \%$ of adults have antibody against the viruses [15].

Accordingly, latent form of BK virus is prevalent in several ethnic populations [16]. Following Immunosuppression and also interactions of the cellular proteins with the large $\mathrm{T}$ antigen, $\mathrm{BK}$ virus is re-activated and induces the polyomavirus related complications such as nephropathy $[16,17]$. Due to the sequences of the transcriptional control regions, BK virus is divided to two different forms, archetype and rearranged variants [18]. Archetype can be separated from urine in both latent and activated forms and also is the transmissible form, while rearranged variants present in the serum/plasma samples of BK reactivated patients [19, 20]. BK virus reactivation is a main cause of nephropathy and hemorrhagic cystitis in the infected patients [12-14, 21]. Four genotypes, genotypes I (the most prevalent genotype), II, III, and IV, have been reported for the BK virus, which are defined based on the sequence variations in VP1 [22, 23], and are corresponded to the $\mathrm{BK}$ virus serotypes, $\mathrm{BK}, \mathrm{SB}, \mathrm{As}$, and IV, respectively [23], while, JC virus has one VP-1 serotype and 12 subtypes [24]. For more information regarding the genotypes of $\mathrm{BK}$ and $\mathrm{JC}$ viruses, please read the articles by Hirsch et al. [25] and Yogo et al. [26].

Polyomaviruses, including BK and JC viruses are transmitted via the respiratory route (the common route), blood transfusion, fecal/urine oral, and transplantation [27]. The polyomavirus infections may disseminate to the other tissues, such as urinary tract and immune cells, then replicate in the tissue cells $[28,29]$. It has been reported that JC Virus can be associated with PML and nephropathy, while several investigations proved the roles played by BK viruses in the pathogenesis of nephropathy, hemorrhagic cystitis and ureteric strictures $[26,30]$. Additionally, the crucial roles played by polyomavirus middle T-antigen (MMTV-PyMT) in induction of cancers, such as breast cancer, have been documented previously [31].

\section{Chemokines}

Chemokines are small chemotactic cytokines with 8-12 $\mathrm{kDa}$, which share four cysteines to make the chemokine fold. The directions of the cysteines are used in the nomenclature of the chemokines. Accordingly, the chemokines are divided into four groups, including CC, CXC CX3C and XC chemokines [32]. The chemokines perform their functions via interactions with their corresponded receptors (Chemokine receptors), hence, they are called as "Ligand", hence, the $\mathrm{CC}, \mathrm{CXC} \mathrm{CX} 3 \mathrm{C}$ and $\mathrm{XC}$ chemokines are called CCLs, CXCLs, CX3CL1 (this group has one member) and XCls [33]. The CC chemokines, which are known as $\beta$-chemokines, consist of 27 distinct members. Although there are CCL1 to CCL28, it has been reported that CCL9 and CCL10 are the same chemokines [33]. There are 17 different CXC chemokines, which are known as $\alpha$-chemokines, in the mammalian. The CXC chemokines are divided into two main categories, ELR (glutamic acid-leucinearginine) positive and negative, due to the existence or lack of the specific motif before the first cysteine [34]. The ELR positive chemokines, such as CXCL8, are the main chemotactic factors for neutrophils, via interactions with CXCR1 and CXCR2, while the ELR negative chemokines, such as CXCL13, play key roles in the attraction of lymphocytes [35]. XCL1 (lymphotactin- $\alpha$ ) and XCL2 (lymphotactin- $\beta$ ), which are known as $\gamma$ chemokines, are two members of the $\mathrm{XC}$ chemokines and participate in the dendritic-cellmediated cytotoxic immune response and attractions of the $\mathrm{CD}^{+}$and $\mathrm{CD} 4^{+} \mathrm{T}$ cells, respectively [36]. CX3C 
chemokines, which are also known as $\delta$-chemokines, have one member entitled CX3CL1 or fractalkine, and play two distinct roles as chemoattractant and as an adhesion molecule [37].

The primary functions of most chemokines are induction of inflammation, especially after viral infections. However, they play key roles in other immune response functions, such as angiogenesis/angiostasis and development of tissues [6]. Figure 1 illustrates the chemokine family and their functions. Thus, next sections of this project describe the plausible critical roles played by chemokines during polyomavirus infections.

\section{Chemokines and polyomaviruses}

The searching in the database centers, including Google scholar, Pubmed and Scopus, revealed that there were no investigations regarding the relationship between polyomaviruses and $\mathrm{CX} 3 \mathrm{C}$ and $\mathrm{XC}$ chemokines. However, several investigations evaluated the roles played by $\mathrm{CC}$ and CXC chemokines during exposure to polyomaviruses. Accordingly, several investigations demonstrated that polyomaviruses are the main causes of chemokines up-regulation. For example, Marzocchetti et al., reported that JC virus is a main inducer of CCL2 expression in the cerebrospinal fluid of the infected patients [38]. A study by De-Simone et al., demonstrated that, although

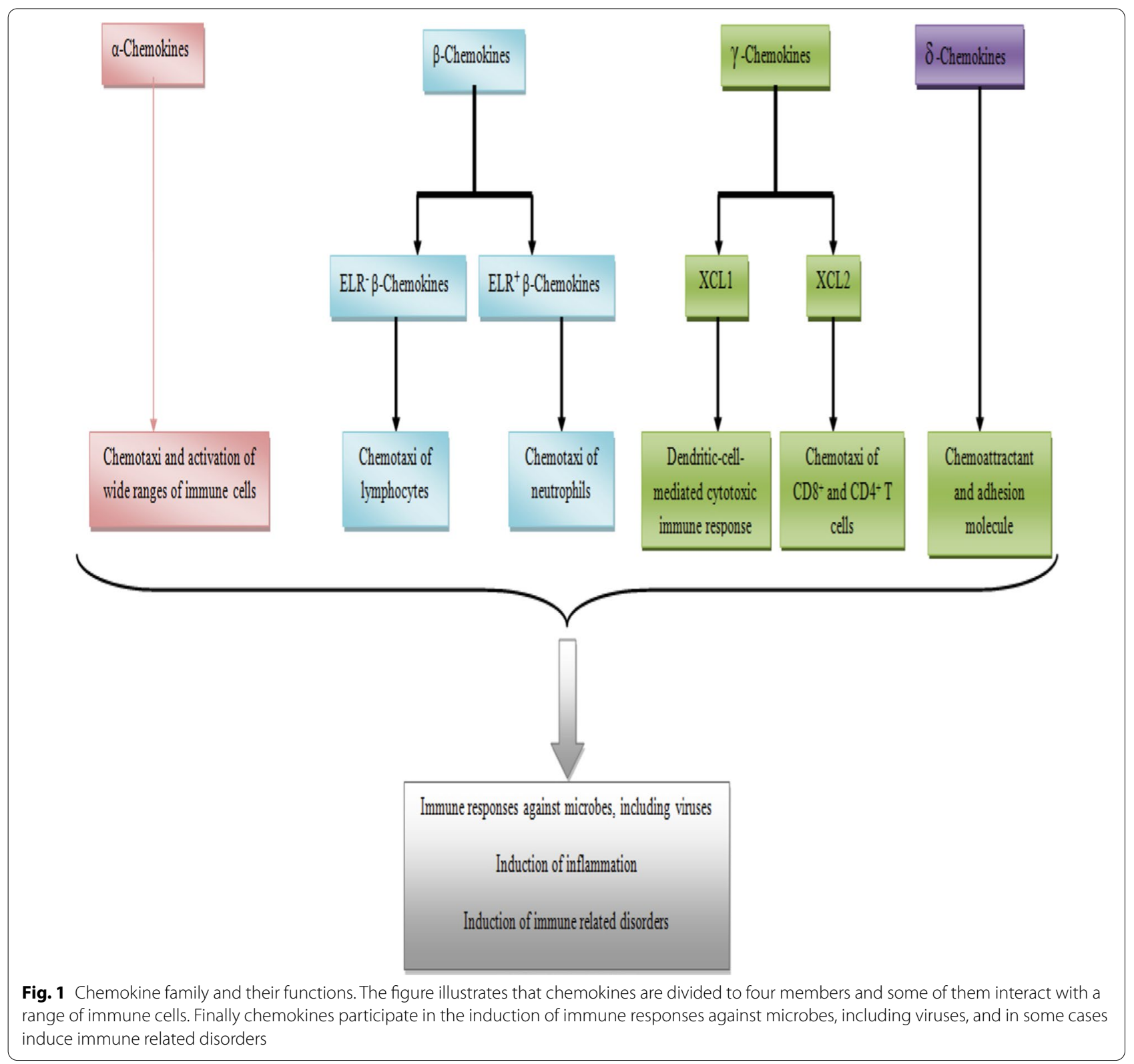


JC virus infection leads to up-regulation of CCL5, it reduced expression of CXCL9 and CCL2 chemokines in the peripheral blood mononuclear cells (PBMCs) [39]. Another study by Cason and colleagues showed that CCL5 and CXCL9, the important factors that participate in the induction of cell differentiation, transformation, and chronic inflammation in the mesenchymal stromal cells, are up-regulated following infection with polyomaviruses such as JC virus [40]. Previous investigations revealed that CCL5 plays potential roles against viral infections via recruitment of $\mathrm{T}$ cells and other leukocytes into infected sites and also induction of either proliferation or activation of natural killer (NK) cells, the most important innate immune cell against viral infected cells [41]. Our previous investigations on the patients with kidney transplantation revealed that BK virus induces kidney nephropathy in the patients via up-regulation of CXCL9 [42], CXCL10 [43], and CXCL11 [44]. Increased expression of CXCL10 by BK virus infected endothelial cells have also been reported by An and colleagues [45]. However, BK virus regulates expression of CXCL9 and CXCL11 at both transcription and translation levels, while it regulates CXCL10 at translation levels only [4244]. Schachtner et al. [46] and Jackson et al. [47] also confirmed the results and reported that BK virus replication has a positive correlation with up-regulation of CXCL9 and CXCL10. Due to the fact that CXCL9 and CXCL10 significantly increased recruitment of cytotoxic lymphocytes (CTLs), NK cells, NK-T cells and macrophages [48, 49], hence, the chemokines play key roles in suppression of viral infections, including polyomaviruses. Therefore, it seems that polyomaviruses play key roles in the induction of expression of the chemokines and in some cases, they regulate the expression of the molecules to overcome immune responses and also induction of some tumor associated functions such as angiogenesis. However, it has been demonstrated that, alteration in expression of the chemokines by polyomaviruses is related to interactions of the viruses by the innate immunity receptors such as toll like receptors (TLRs) and intracellular sensors such as retinoic acid inducible gene-I (RIG-I) [50]. In other words, interactions of polyomaviruses with innate immune receptors lead to regulation of expression of the chemokines, which may make activation of normal immune responses to the viruses and eradication/suppression of them possible. Several investigations proved the roles played by chemokines against viral infections to overcome the microbes [51-53], thus, it is plausible that chemokines play key roles against polyomaviruses too. Above investigations also proved the roles played by chemokines against polyomaviruses. However, there are some documents which demonstrated that chemokines are unable to inhibit JC virus replication and also its gene expression in the glial and primary human astrocytes cells [39]. Non-interestingly chemokines in association with other immune responses are the most common weapon against polyomaviruses and are the main mechanisms for suppression of the viruses in the immune-compatible individuals.

Chemokines also may reduce polyomaviruses-related pathological functions. For example, Gao et al., reported that CCL5, via interaction with CCR5, significantly participates in the reduction of polyomavirus middle T-antigen (MMTV-PyMT) related mouse primary breast cancer through the attraction of immune cells, decreases expression of glucose transporter-1 (GLUT-1) cell surface, and subsequently decreases glucose uptake and also the intracellular AATP and lactate levels [31].

The roles of the chemokines in the pathogenesis of polyomaviruses are the main research fields of the investigators. Thus, recent studies explore the negative roles played by chemokines during polyomaviruses infections. A study by Comar et al., showed that polyomaviruses deteriorate the pathogenesis of Malignant Mesothelioma via induction of CCL5 expression in the in vivo condition [54]. Steiner and colleagues demonstrated that using bindarit, as a CCL2 synthesis inhibitor, leads to suppression of polyomavirus-related breast cancer development by down-regulation of CCL2 in the tumor tissue, but not in the plasma [55]. Interestingly, a study in the Merkel cell polyomavirus (MCV) showed that polyomavirus large $\mathrm{T}$ antigen, plays positive roles in up-regulation of CXCL12 and its related receptors, including CXCR3 and CXCR4 [56]. Another study demonstrated that polyomaviruses induces expression of CCL2 and CXCL12 to recruit tumor associated macrophages to the polyomavirus-related breast cancer tissue [57]. Tumor associated macrophages are the important cells to increase tumor progression and metastasis [58]. Additionally, it has been demonstrated that CCL2 and CXCL12 are the potential chemokines to induce angiogenesis, the main mechanisms that lead to tumors development [33]. Boyle and colleagues showed that CCR6, the chemokine receptor for CCL20, through recruitment of tumor associated macrophages, plays key roles in the induction of polyomavirus-related mammary neoplasia [59]. The roles played by the polyomavirus large and small $\mathrm{T}$ antigens in the induction of expression of CXCL8 in the MCV have been documented by Richards and colleagues [60]. The investigators demonstrated that expression of the proinflammatory chemokine is a main cause of malignancy in the cell line [60]. Thus, it appears that chemokines are the important molecules which are used by polyomaviruses to develop polyomaviruses-related cancers through an increase in angiogenesis and recruitment of some immunosuppressor cells to the tumor tissues. 
Additionally, it has been documented that polyomaviruses are the main causes of nephropathy. Ribeiro et al., reported that BK virus induces transplantation associated nephropathy by up-regulation of CCL5 and CXCL8 in tumor necrosis factor (TNF) $\alpha / \mathrm{TNF}$ receptor system dependent manner [61]. The positive correlation between expression of intragraft tubulointerstitial cell CCL2 and polyomavirus replication can be considered as a risk for induction of nephropathy in the transplanted kidney [62]. A study by Ho et al., revealed that up-regulation of CXCL10 in the urine of the patients who suffered from renal allograft inflammation has increased tissue BK virus load [63]. Our previous investigations also proved the roles played by CXCL9, CXCL10 and CXCL11 in the induction of nephropathy in the BK virus infected patients who underwent kidney transplantation [42-44]. CXCL10 is a molecule that suppresses angiogenesis [49] and, hence, it may be concluded that the molecule might increase the nephropathy risk via either suppression of angiogenesis and tissue repair or elevation of inflammation. Therefore, chemokines are the important molecules in induction of polyomaviruses-related nephropathy too. As mentioned previously, JC virus is the main cause of PML in the human [26,30]. Due to the closed relation between polyomaviruses and chemokines, it is plausible that chemokines may participate in the pathogenesis of PML. Darbinyan and colleagues reported that JC virus suppresses differentiation of oligodendrocyte progenitor cells, a main mechanism which leads to PML, via dysregulation of CCL5, CXCL1, CXCL5, CXCL8, CXCL10 and CXCL16 [64]. Another investigation proved the roles played by JC viruses and revealed that JC virus agnoprotein is the main molecule responsible for reduction of CXCL5, and consequently, activation of apoptotic signaling pathways in the neurons, the main mechanism for induction of PML [65]. Thus, it may be concluded that chemokines, especially CXC chemokines play significant roles in the pathogenesis of PML. However, it needs to be explored by further studies via investigations of other CC chemokines and also CX3C and XC chemokines. Additionally, the roles played by polyomaviruses in the induction of gynaecological disease in CXCL8 dependent manner have also been demonstrated by Zhang and colleagues [66]. A complementary investigation showed that the polyomavirus large $\mathrm{T}$ antigen is the molecule responsible for up-regulation of CXCL8 [67]. Based on the fact that CXCL8 is the main chemotactic factor for neutrophils [33], it may be hypothesized that polyomaviruses induce gynaecological diseases by increasing inflammation in neutrophil dependent manner.

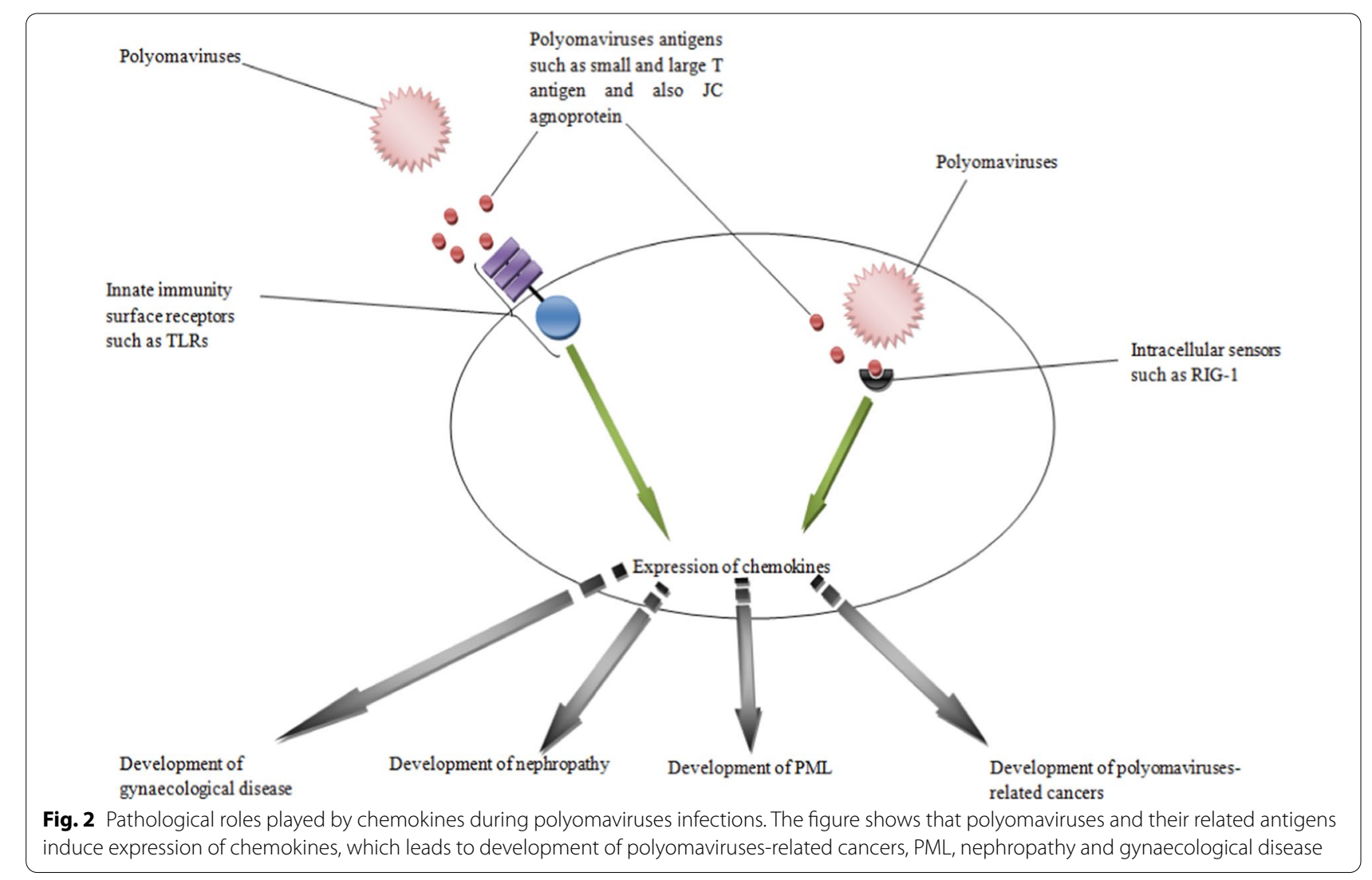


The main mechanisms which lead to altered expression of the chemokines during polyomaviruses infections in the human are yet to be clarified. It has been hypothesized that genetic variations within the chemokine genes can be associated with alteration in expression of the chemokines [68]. Multiple investigations regarding the genetic variations within chemokine genes and their relations with polyomaviruses related diseases do not exist. However, a genetic study by Guerini and colleagues revealed that there is an association between CCL5, but not CCR5, CCR2, CXCL12, single nucleotide polymorphism (SNP) and severity of JC virus-related PML [69]. Thus, it appears that more investigations need to be performed to clear the roles played by genetic variations in the outcome of polyomaviruses infections and their related pathogenesis.

\section{Conclusion}

Collectively, chemokines play significant roles against polyomaviruses and suppress them, however, they are the critical responsible molecules that participate in the polyomaviruses related pathogenesis, including development of tumors, nephropathy, gynaecological disease and PML. Figure 2 illustrates the main physiological and pathological roles played by chemokines during polyomaviruses infections. Due to the results it may also be concluded that CXC chemokines, including CXCL1, CXCL5, CXCL8, CXCL9, CXCL10, CXCL11, CXCL12 and CXCL16, significantly participate in the pathogenesis of polyomaviruses. CC chemokines, such as CCL2, CCL5 and CCL20 also participate in the induction of pathological conditions. Therefore, it can be hypothesized that future investigations using specific antagonists for chemokines, for instance using antagonist for CXCL10 in nephropathy, can open an avenue to development of molecular therapy of polyomaviruses related disorders. Additionally, immunotherapy against some specific chemokines such as CCL2 may alter the polyomavirusesrelated tumor microenvironment, which needs to be explored by future studies.

\begin{abstract}
Abbreviations
PML: Progressive multifocal leukoencephalopathy; CXCL: CXC ligand; VP: Capsid proteins; JC: John Cunningham; ELR: Glutamic acid-leucine-arginine; PBMCs: Peripheral blood mononuclear cells; TLR: Toll like receptor; RIG-I: Retinoic acid inducible gene-l; MMTV-PyMT: Polyomavirus middle T-antigen; GLUT-1: Glucose transporter-1; MCV: Merkel cell polyomavirus; TNF: Tumor necrosis factor; SNP: Single nucleotide polymorphism.
\end{abstract}

Acknowledgements

Not applicable.

\section{Authors' contributions}

MHM has collected the data and written the manuscript draft. AK has collected the data and completed the manuscript. Both authors read and approved the final manuscript.

\section{Funding}

Islamic Azad University, Kerman Branch funded the project.

\section{Availability of data and materials}

Data and materials are available.

\section{Declarations}

Ethics approval and consent to participate

Not applicable.

Consent to publication

Not applicable.

\section{Competing interests}

There is no competing interest to declare.

\section{Author details}

${ }^{1}$ Department of Pediatrics, Faculty of Medicine, Zabol University of Medical Sciences, Zabol, Iran. ${ }^{2}$ Department of Microbiology, Kerman Branch, Islamic Azad University, Kerman, Iran.

Received: 13 July 2020 Accepted: 19 May 2021

Published online: 03 June 2021

\section{References}

1. Van Ghelue M, Khan MT, Ehlers B, Moens U. Genome analysis of the new human polyomaviruses. Rev Med Virol. 2012;22(6):354-77.

2. Kariminik A. IL-2 and polyoma BK virus infection; a systematic review article. Cytokine. 2016;88:276-80.

3. Ahsan N, Shah KV. Polyomaviruses and human diseases. Adv Exp Med Biol. 2006;577:1-18.

4. White MK, Gordon J, Reiss K, Del Valle L, Croul S, Giordano A, et al. Human polyomaviruses and brain tumors. Brain Res Brain Res Rev. 2005;50(1):69-85.

5. Kariminik A, Yaghobi R, Dabiri S. Innate immunity and BK virus: prospective strategies. Viral Immunol. 2016;29(2):74-82.

6. Bodnar RJ. Chemokine regulation of angiogenesis during wound healing. Adv Wound Care (New Rochelle). 2015;4(11):641-50.

7. Myhre MR, Olsen G-H, Gosert R, Hirsch HH, Rinaldo CH. Clinical polyomavirus BK variants with agnogene deletion are non-functional but rescued by trans-complementation. Virology. 2010;398(1):12-20.

8. Kariminik A, Kheirkhah B. Tumor growth factor-beta is an important factor for immunosuppression and tumorgenesis in Polyoma BK virus infection; a systematic review article. Cytokine. 2017;95:64-9.

9. Darbinyan A, Siddiqui KM, Slonina D, Darbinian N, Amini S, White $M K$, et al. Role of JC virus agnoprotein in DNA repair. J Virol. 2004:78(16):8593-600.

10. Panou MM, Prescott EL, Hurdiss DL, Swinscoe G, Hollinshead M, Caller $L G$, et al. Agnoprotein is an essential egress factor during BK polyomavirus infection. Int J Mol Sci. 2018;19(3):902.

11. Trofe-Clark J, Sawinski D. BK and other polyomaviruses in kidney transplantation. Semin Nephrol. 2016;36(5):372-85.

12. Padilla-Fernandez B, Bastida-Bermejo J, Virseda-Rodriguez A, LabradorGomez J, Caballero-Barrigon D, Silva-Abuin J, et al. Hemorrhagic cytitis after bone marrow transplantation. Arch Esp Urol. 2014;67(2):167-74.

13. Sharma SG, Nickeleit V, Herlitz LC, de Gonzalez AK, Stokes MB, Singh $H K$, et al. BK polyoma virus nephropathy in the native kidney. Nephrol Dial Transplant. 2013;28(3):620-31.

14. Shakiba E, Yaghobi R, Ramzi M. Prevalence of viral infections and hemorrhagic cystitis in hematopoietic stem cell transplant recipients. Exp Clin Transplant. 2011;9(6):405-12. 
15. Knowles WA. Discovery and epidemiology of the human polyomaviruses BK virus (BKV) and JC virus (JCV). Adv Exp Med Biol. 2006:577:19-45.

16. Van Aalderen M, Heutinck K, Huisman C, Ten Berge I. BK virus infection in transplant recipients: clinical manifestations, treatment options and the immune response. Neth J Med. 2012;70(4):172-83.

17. Kwun HJ, Chang Y, Moore PS. Protein-mediated viral latency is a nove mechanism for Merkel cell polyomavirus persistence. Proc Natl Acad Sci U S A. 2017:114(20):E4040-7.

18. Olsen $\mathrm{GH}$, Hirsch $\mathrm{HH}$, Rinaldo $\mathrm{CH}$. Functional analysis of polyomavirus BK non-coding control region quasispecies from kidney transplant recipients. J Med Virol. 2009;81(11):1959-67.

19. Olsen GH, Andresen PA, Hilmarsen HT, Bjørang O, Scott H, Midtvedt $\mathrm{K}$, et al. Genetic variability in BK Virus regulatory regions in urine and kidney biopsies from renal-transplant patients. J Med Virol. 2006;78(3):384-93.

20. Broekema NM, Imperiale MJ. Efficient propagation of archetype BK and JC polyomaviruses. Virology. 2012;422(2):235-41.

21. Geramizadeh B, Roozbeh J, Malek-Hosseini S-A, Azarpira N, Ayatollahi $\mathrm{M}$, Salahi $\mathrm{H}$, et al. Urine cytology as a useful screening method for polyoma virus nephropathy in renal transplant patients: a single-center experience. Transplant Proc. 2006;38(9):2923-5.

22. Kaydani GA, Makvandi M, Samarbafzadeh A, Shahbazian H, Fard MH. Prevalence and distribution of BK virus subtypes in renal transplant recipients referred to golestan hospital in Ahvaz, Iran. Jundishapur J Microbiol. 2015;8(3):e16738.

23. Baksh FK, Finkelstein SD, Swalsky PA, Stoner GL, Ryschkewitsch CF, Randhawa P. Molecular genotyping of BK and JC viruses in human polyomavirus [ndash] associated interstitial nephritis after renal transplantation. Am J Kidney Dis. 2001;38(2):354-65.

24. Yogo Y, Sugimoto C, Zheng HY, Ikegaya H, Takasaka T, Kitamura T. JC virus genotyping offers a new paradigm in the study of human populations. Rev Med Virol. 2004;14(3):179-91.

25. Hirsch HH, Kardas P, Kranz D, Leboeuf C. The human JC polyomavirus (JCPyV): virological background and clinical implications. APMIS. 2013;121(8):685-727

26. Yogo Y, Sugimoto C, Zhong S, Homma Y. Evolution of the BK polyomavirus: epidemiological, anthropological and clinical implications. Rev Med Virol. 2009;19(4):185-99.

27. Boldorini R, Allegrini S, Miglio U, Paganotti A, Cocca N, Zaffaroni M, et al. Serological evidence of vertical transmission of JC and BK polyomaviruses in humans. J Gen Virol. 2011;92(5):1044-50.

28. Dharnidharka VR, Abdulnour HA, Araya CE. The BK virus in renal transplant recipients-review of pathogenesis, diagnosis, and treatment. Pediatr Nephrol. 2011;26(10):1763-74.

29. Portolani M, Piani M, Gazzanelli G, Borgatti M, Bartoletti A, Grossi M, et al. Restricted replication of BK virus in human lymphocytes. Microbiologica. 1985;8(1):59-66.

30. Hirsch $\mathrm{HH}$. Virology, epidemiology, and pathogenesis of JC polyomavirus, BK polyomavirus, and other human polyomaviruses. UpToDate. 2019.

31. Gao D, Cazares LH, Fish EN. CCL5-CCR5 interactions modulate metabolic events during tumor onset to promote tumorigenesis. BMC Cancer. 2017;17(1):834.

32. Legler DF, Thelen M. Chemokines: chemistry, biochemistry and biological function. Chimia (Aarau). 2016;70(12):856-9.

33. Laing KJ, Secombes CJ. Chemokines. Dev Comp Immunol. 2004;28(5):443-60.

34. Pontejo SM, Murphy PM. Chemokines encoded by herpesviruses. J Leukoc Biol. 2017;102(5):1199-217.

35. Bizzarri C, Beccari AR, Bertini R, Cavicchia MR, Giorgini S, Allegretti M. ELR+ CXC chemokines and their receptors (CXC chemokine receptor 1 and CXC chemokine receptor 2) as new therapeutic targets. Pharmacol Ther. 2006:112(1):139-49.

36. Lei Y, Takahama Y. XCL1 and XCR1 in the immune system. Microbes Infect. 2012;14(3):262-7.

37. Liu W, Jiang $L$, Bian C, Liang Y, Xing R, Yishakea $M$, et al. Role of CX3CL1 in diseases. Arch Immunol Ther Exp (Warsz). 2016;64(5):371-83.

38. Marzocchetti A, Cingolani A, Giambenedetto SD, Ammassari A, Giancola ML, Cauda R, et al. Macrophage chemoattractant protein-1 levels in cerebrospinal fluid correlate with containment of JC virus and prognosis of acquired immunodeficiency syndrome-associated progressive multifocal leukoencephalopathy. J Neurovirol. 2005; 11(2):219-24

39. De-Simone Fl, Sariyer R, Otalora YL, Yarandi S, Craigie M, Gordon J, et al. IFN-Gamma inhibits JC virus replication in glial cells by suppressing T-antigen expression. PLoS ONE. 2015;10(6):e0129694.

40. Cason C, Campisciano G, Zanotta N, Valencic E, Delbue S, Bella R, et al. SV40 infection of mesenchymal stromal cells from Wharton's jelly drives the production of inflammatory and tumoral mediators. J Cell Physiol. 2017;232(11):3060-6.

41. Marques RE, Guabiraba R, Russo RC, Teixeira MM. Targeting CCL5 in inflammation. Expert Opin Ther Targets. 2013;17(12):1439-60.

42. Kariminik A, Yaghobi R, Dabiri S. CXCL9 expression and polyomavirus BK infectivity in renal transplant patients with nephropathy. Cell Mol Biol (Noisy-le-grand). 2016;62(1):104-8.

43. Kariminik A, Dabiri S, Yaghobi R. Polyomavirus BK induces inflammation via up-regulation of CXCL10 at translation levels in renal transplant patients with nephropathy. Inflammation. 2016;39(4):1514-9.

44. Kariminik A, Yaghobi R, Dabiri S. Association of BK virus infection with CXCL11 gene expression and protein levels in kidney transplant patients. Exp Clin Transplant. 2018;16(1):50-4.

45. An P, Sáenz Robles MT, Duray AM, Cantalupo PG, Pipas JM. Human polyomavirus BKV infection of endothelial cells results in interferon pathway induction and persistence. PLoS Pathog. 2019;15(1):e1007505.

46. Schachtner T, Stein M, Sefrin A, Babel N, Reinke P. Inflammatory activation and recovering BKV-specific immunity correlate with self-limited BKV replication after renal transplantation. Transpl Int. 2014;27(3):290-301.

47. Jackson JA, Kim EJ, Begley B, Cheeseman J, Harden T, Perez SD, et al. Urinary chemokines CXCL9 and CXCL10 are noninvasive markers of renal allograft rejection and BK viral infection. Am J Transplant. 2011;11(10):2228-34.

48. Dufour JH, Dziejman M, Liu MT, Leung JH, Lane TE, Luster AD. IFNgamma-inducible protein 10 (IP-10; CXCL10)-deficient mice reveal a role for IP-10 in effector T cell generation and trafficking. J Immunol. 2002;168(7):3195-204.

49. Angiolillo AL, Sgadari C, Taub DD, Liao F, Farber JM, Maheshwari S, et al. Human interferon-inducible protein 10 is a potent inhibitor of angiogenesis in vivo. J Exp Med. 1995;182(1):155-62.

50. Ribeiro A, Wornle M, Motamedi N, Anders HJ, Grone EF, Nitschko H, et al. Activation of innate immune defense mechanisms contributes to polyomavirus BK-associated nephropathy. Kidney Int. 2012;81(1):100-11.

51. Lim JK, Murphy PM. Chemokine control of West Nile virus infection. Exp Cell Res. 2011;317(5):569-74.

52. Yoshio S, Mano Y, Doi H, Shoji H, Shimagaki T, Sakamoto Y, et al. Cytokine and chemokine signatures associated with hepatitis B surface antigen loss in hepatitis B patients. JCI Insight. 2018;3(20):122268.

53. Chi Y, Zhu Y, Wen T, Cui L, Ge Y, Jiao Y, et al. Cytokine and chemokine levels in patients infected with the novel avian influenza A (H7N9) virus in China. J Infect Dis. 2013;208(12):1962-7.

54. Comar M, Zanotta N, Bonotti A, Tognon M, Negro C, Cristaudo A, et al. Increased levels of C-C chemokine RANTES in asbestos exposed workers and in malignant mesothelioma patients from an hyperendemic area. PLoS ONE. 2014;9(8):e104848.

55. Steiner JL, Davis JM, McClellan JL, Guglielmotti A, Murphy EA. Effects of the MCP-1 synthesis inhibitor bindarit on tumorigenesis and inflammatory markers in the C3(1)/SV40Tag mouse model of breast cancer. Cytokine. 2014;66(1):60-8.

56. Wheat R, Roberts C, Waterboer T, Steele J, Marsden J, Steven NM, et al. Inflammatory cell distribution in primary merkel cell carcinoma. Cancers (Basel). 2014;6(2):1047-64.

57. Tran K, Risingsong R, Royce D, Williams CR, Sporn MB, Liby K. The synthetic triterpenoid CDDO-methyl ester delays estrogen receptor-negative mammary carcinogenesis in polyoma middle T mice. Cancer Prev Res (Phila). 2012;5(5):726-34.

58. Ngambenjawong C, Gustafson HH, Pun SH. Progress in tumor-associated macrophage (TAM)-targeted therapeutics. Adv Drug Deliv Rev. 2017;15(114):206-21.

59. Boyle ST, Faulkner JW, McColl SR, Kochetkova M. The chemokine receptor CCR6 facilitates the onset of mammary neoplasia in the MMTV-PyMT mouse model via recruitment of tumor-promoting macrophages. Mol Cancer. 2015;14(115):115. 
60. Richards KF, Guastafierro A, Shuda M, Toptan T, Moore PS, Chang Y. Merkel cell polyomavirus $T$ antigens promote cell proliferation and inflammatory cytokine gene expression. J Gen Virol. 2015;96(12):3532-44.

61. Ribeiro A, Merkle M, Motamedi N, Nitschko H, Koppel S, Wornle M. BK virus infection activates the TNFalpha/TNF receptor system in Polyomavirus-associated nephropathy. Mol Cell Biochem. 2016;411(1-2):191-9.

62. Boratynska M, Dubinski B, Rybka K, Jezior D, Szyber P, Klinger M. Immunocytological urinalysis and monocyte chemotactic peptide-1 in renal transplant recipients with polyomavirus replication. Transplant Proc. 2006;38(1):151-4

63. Hornsby E, Pfeffer PE, Laranjo N, Cruikshank W, Tuzova M, Litonjua AA, et al. Vitamin D supplementation during pregnancy: effect on the neonatal immune system in a randomized controlled trial. J Allergy Clin Immunol. 2018;141(1):269-278.e1.

64. Darbinyan A, Kaminski R, White MK, Darbinian-Sarkissian N, Khalili K. Polyomavirus JC infection inhibits differentiation of oligodendrocyte progenitor cells. J Neurosci Res. 2013;91(1):116-27.

65. Merabova N, Kaminski R, Krynska B, Amini S, Khalili K, Darbinyan A. JCV agnoprotein-induced reduction in CXCL5/LIX secretion by oligodendrocytes is associated with activation of apoptotic signaling in neurons. J Cell Physiol. 2012;227(8):3119-27.
66. Zhang XY, Guckian M, Nasiri N, Lovell PA, Dalgleish AG, Barton DP. Normal and SV40 transfected human peritoneal mesothelial cells produce IL-6 and IL-8: implication for gynaecological disease. Clin Exp Immunol. 2002;129(2):288-96.

67. Asamitsu K, Sakurada S, Mashiba K, Nakagawa K, Torikai K, Onozaki K, et al. Alteration of the cellular response to interleukin-1 beta by SV40 large T antigen in rheumatoid synovial fibroblasts. Arch Virol. 1999;144(2):317-27.

68. Qidwai T. Chemokine genetic polymorphism in human health and disease. Immunol Lett. 2016;176:128-38.

69. Guerini FR, Delbue S, Zanzottera M, Agliardi C, Saresella M, Mancuso R, et al. Analysis of CCR5, CCR2, SDF1 and RANTES gene polymorphisms in subjects with HIV-related PML and not determined leukoencephalopathy. Biomed Pharmacother. 2008;62(1):26-30.

\section{Publisher's Note}

Springer Nature remains neutral with regard to jurisdictional claims in published maps and institutional affiliations.
Ready to submit your research? Choose BMC and benefit from:

- fast, convenient online submission

- thorough peer review by experienced researchers in your field

- rapid publication on acceptance

- support for research data, including large and complex data types

- gold Open Access which fosters wider collaboration and increased citations

- maximum visibility for your research: over $100 \mathrm{M}$ website views per year

At BMC, research is always in progress.

Learn more biomedcentral.com/submissions 